\title{
В.І. МЕЛЬНИК
}

Національний ботанічний сад імені М.М. Гришка НАН України

вул. Тимірязєвська, 1, м. Київ, 01014, Україна

flora@nbg.kiev.ua

ЙОСИП КОНРАДОВИЧ ПАЧОСЬКИЙ (до 150-річчя від дня народження)

Ключ о в і сло в а: Й.К. Пачоський, ботаніка, флора, систематика рослин, фітосоціологія, зоологія

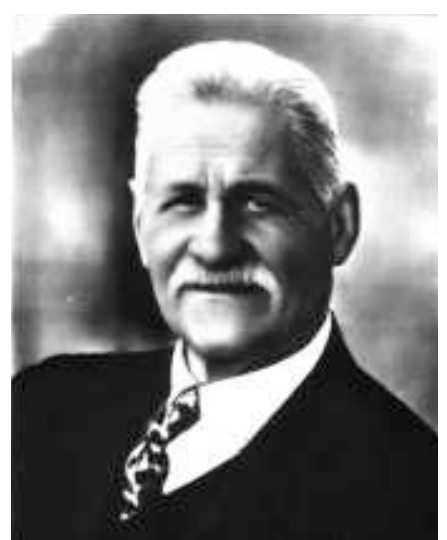

На засіданні Київського товариства природознавців 30 січня 1888 року професор зоології Київського університету св. Володимира І.В. Бобрецький, який клопотався про надання наукового відрядження молодому 24-літньому Йосипу (Юзефу) Пачоському, сказав: «Пан Пачоський однаковою мірою володіє знаннями як із систематики рослин, так із систематики тварин, являючи собою такий рідкісний нині тип натураліста в ліннеєвському розумінні». Таким «натуралістом у ліннеєвському розумінні» Йосип Пачоський залишався усе життя. Він зробив неоціненний внесок у розвиток ботаніки, зоології, лісознавства, охорони природи, наукознавства.

(С) В.І. МЕЛЬНИК, 2014
Йосип (Юзеф) Конрадович Пачоський, український і польський ботанік, народився 8 грудня 1864 року в польській родині в с. Білогородка Волинської губернії (нині Ізяславський район Хмельницької області). 3 дитячих років він дуже цікавився навколишньою природою. Понад усе любив екскурсії до лісу. І цю любов до природи зберіг до кінця своїх днів. Він закінчив Рівненське реальне училище й Уманське училище землеробства та садівництва. Його першим учителем ботаніки в Умані був Владислав Скробишевський, який згодом став науковим співробітником Нікітського ботанічного саду в Криму. Свою вдячність учителеві Й. Пачоський виразив, назвавши на його честь новий для науки вид рослин, - Cytisus skrobiszewskii. Від 1888 року Йосип Пачоський працює лаборантом-садівником у Ботанічному саду Київського університету. В 1894 р. він вивчає ботаніку під керівництвом професора цього ж університету - відомого флориста, автора «Флоры Средней и Южной России» І.Ф. Шмальгаузена. Однак навчання Йосип Пачоський не завершив і диплом про закінчення університету не отримав.

У 1897 році Й.К. Пачоський стає активним членом Київського товариства дослідників природи, керівництво якого систематично відряджає його в різні регіони країни для вивчення флори та фауни. 31888 по 1893 рік він досліджує рослинність причорноморських степів, пониззя Дону та Дунаю, 
Криму й Кавказу, калмицьких степів. Й.К. Пачоський неодноразово виступав на засіданнях товариства 3 науковими повідомленнями про свої експедиційні дослідження. У «Записках Киевского общества естествоиспытателей» були опубліковані його перші наукові праці - «Очерки флоры окрестностей г. Умани» (1887), «Материалы для флоры Заславского и Ковельского уездов Волынской губернии» (1888), «О фауне и флоре окрестностей г. Владимира-Волынского» (1888), «О растительности г. Николаева» (1889), «Описание новых и малоизвестных растений Херсонской губернии» (1889) та ін.

У 1894 р. Й.К. Пачоський переїздить до Петербурга та влаштовується на роботу в Ботанічний сад, де в 1894-1895 рр. виконує обов'язки помічника хранителя музею. Влітку 1894 р. за завданням Департаменту земельних поліпшень Пачоського відрядили до Полісся для вивчення впливу осушення боліт на рослинність. Отримані матеріали стали основою капітальних ботанічних праць ученого - «Флора Полесья и прилежащих местностей» (1897-1900) та «O formacjach roślinnych і о pochodzeniu flory poleskiej» (1900).

Навесні 1895 р. Йосип Пачоський переїздить із Петербурга до м. Дубляни, що поблизу Львова, де працює асистентом на кафедрі ботаніки Сільськогосподарського інституту. В цей період він здійснює польові дослідження флори Західного Поділля, Буковини, Угорщини, Бессарабії.

У 1897 р. Херсонська земська управа запросила Й.К. Пачоського на посаду губернського ентомолога. Відтоді починається тривалий -25 -річний період у житті вченого, пов'язаний із роботою на півдні України. Головним завданням Й.К. Пачоського як ентомолога було вивчення шкідників сільського господарства та розроблення заходів для боротьби з ними.

Роботу в Херсоні Пачоський розпочав із заснування ентомологічного музею, який незабаром перетворився на Природничий музей. Учений був призначений його директором. Він керував музеєм із 1898 по 1922 рік. У 1906 р. дослідник публікує «Объяснительный каталог естественноисторического музея Херсонского губернского земства». Ентомологічна комісія передала музею колекцію птахів і ссавців А.А. Браунера і гербарій I.3. Рябкова (686 видів). Йосип Конрадович зібрав великі колекції рослин, комах, птахів, риб, мінералів. Гербарій постійно поповнювався його зборами не тільки з Херсонської губернії, а й із інших тери- торій - Волинської, Київської, Люблінської, Подільської, Полтавської губерній, а також Криму, Кавказу, Татр, Галичини, Австрії, Угорщини. Станом на 1905 р. колекція рослин нараховувала 6000 зразків 1500 видів. Із перших днів існування музею Й.К. Пачоський обмінювався дуплетами з багатьма ботаніками та гербаріями світу. Внаслідок інтенсивного надходження матеріалів у 1909 р. в музеї нараховувалось уже близько 20 тисяч гербарних аркушів. У 1897-1919 рр. учений зібрав колекцію плодів і насіння рослин загальною кількістю 976 зразків. При музеї була створена бібліотека, яка постійно поповнювалася новими книгами та журналами. Таким чином, музей став великим науковим центром на півдні України.

Для популяризації відомостей про шкідливих комах Й.К. Пачоський писав статті, які друкувалися в газетах «Юг», «Известия Елисаветградского общества сельского хозяйства». В «Сборнике Херсонского земства» він публікував щорічні звіти про свою діяльність.

Працюючи в Херсоні, Йосип Конрадович здійснював польові дослідження флори та фауни. Багато уваги він приділив вивченню рослинного покриву Дніпровського повіту Херсонської губернії (нині Цюрупинський р-н Херсонської обл.). Починаючи з 1902 р. за матеріалами своїх польових досліджень він публікує два випуски ботаніко-географічного нарису «По пескам Днепровского уезда».

3 особливим інтересом Й.К. Пачоський вивчав рослинний покрив Асканії-Нової. Він був ініціатором охорони цього унікального степового комплексу. За його порадою в 1898 р. господар садиби Асканія-Нова Ф.Е. Фальц-Фейн узяв під охорону дві ділянки цілинних степів. Так з'явився один із перших резерватів України.

У цей період Й.К. Пачоський вивчає рослинність не тільки Херсонської губернії. В 1908 р. він здійснив поїздку до Бессарабії, де досліджував Кодри та північну частину Придністров'я. За результатами цієї експедиції вчений видав дві монографії - «Материалы по флоре Бессарабии» (1912) і «Очерк растительности Бессарабии» (1914).

Інтенсивно вивчаючи рослинний покрив, Йосип Конрадович у 1912-1914 рр. навіть свою відпустку провів у експедиціях по Київській і Подільській губерніях. 1913 року в Херсонській губернії він створив спеціальне бюро з вивчення бур'янів, а 1915 року на Аджамській сільськогосподарській дослідній станції - дослідну ділянку. Не полишаючи роботу в музеї, вчений керував 
вивченням біології бур'янів на цій станції. Його помічником був призначений М.І. Лебедєв. Дослідження тривали в 1915-1916 рр., їхнім підсумком стала спільна праця Й.К. Пачоського та М.I. Лебедєва «Результаты исследования сорнополевой растительности на Аджамской сельскохозяйственной опытной станции» (1916).

У 1915-1917 рр. Йосип Конрадович вивчає рослинність долин річок Дніпра, Південного Бугу, Дністра та північного узбережжя Чорного моря. 30 квітня 1917 р. вченого одноголосно обрали почесним членом Товариства сільського господарства Південної Росії.

1918 року в Херсоні був відкритий Політехнічний інститут, де Й.К. Пачоський, не залишаючи роботу в музеї, обійняв посаду професора ботаніки. На агрономічному факультеті він читав лекції 3 морфології рослин і фітосоціології. Ці лекції були настільки цікавими та захоплюючими, що їх відвідували не лише студенти, а й викладачі інституту й усі, хто цікавився проблемами ботаніки.

Лекції Й.К. Пачоського з морфології рослин були опубліковані в 1919-1920 pр. у двох випусках у вигляді підручника «Морфология растений». «Це не описова чи морфологічна органографія, на яку ми натрапляємо в багатьох підручниках і посібниках, - це філософськи продуманий курс, у якому ідея постійної еволюції організмів на земній кулі проходить від початку до кінця», - так високо оцінив підручник видатний ботанік, професор Юр'євського університету М.І. Кузнецов.

1921 року в Херсоні вийшов друком перший у світі підручник із фітосоціології Й.К. Пачоського - «Основы фитосоциологии».

Як уже згадувалося, Йосип Конрадович з особливим інтересом вивчав рослинність заповідника «Асканія-Нова». Після лютневої революції 1917 р. заповідник перейшов у власність держави. На початку цього ж року Міністр - Голова Тимчасового уряду князь Львов призначив Й.К. Пачоського «комісаром Тимчасового уряду для охорони парку з вимираючими видами рідкісних тварин і маєтку “Асканія-Нова”».

Після жовтневої революції в 1919 р. було видано декрет радянської влади про організацію в АсканіїНовій заповідника «Чаплі», який передали у відання Наркомзему України. Навесні 1922 р. Й.К. Пачоського призначили завідувачем ботанічного відділу науково-степової станції цього заповідника. Осінь і зиму 1922-1923 pр. учений провів у Асканії-Новій, займаючись науковою та адміністратив- ною роботою. Результатом стаціонарних спостережень за рослинним покривом заповідного степу стали його публікації «Наблюдения над целинным покровом в Аскания-Новой в 1922 г.» (1928), «Наблюдения над целинным покровом в Аскания-Новой в 1923 г.» (1924) і «Целинная заповедная степь Аскания-Нова» (1924).

У цей період в Асканії-Новій працював молодий талановитий ботанік С.А. Дзевановський, на формування якого як степознавця великий вплив мав Йосип Конрадович. У липні 1922 р. Пачоський, його син Конрад і С.А. Дзевановський організували тритижневу експедицію з Асканії-Нової до Криму - на Ай-Петринську яйлу.

Улітку 1923 р. Й.К. Пачоський і відомий лісознавець Г.М. Висоцький розробляють план Асканійського парку. У вересні того ж року вчений залишає Асканію-Нову і переїздить до Польщі. Причинами цього переїзду було загострення радянськопольських відносин і побоювання Пачоського бути репресованим. На думку американського дослідника історії екології в СРСР Д. Вайнера, «схильність Пачоського поширювати висновки, отримані при вивченні рослинних угруповань, на людське суспільство була сприйнята в Радянській Росії як небезпечна політична єресь. 3 поглядів Пачоського випливало не більше й не менше, як повна безглуздість марксистського експерименту, оскільки, на його думку, класова диференціація була неодмінним атрибутом будь-якого угруповання. Якщо нерівність природна і якщо це можна довести науково, то всі спроби революційним шляхом встановити загальну рівність приречені на невдачу».

У 1923-1928 роках Й.К. Пачоський - перший директор резервату «Біловезька Пуща». Він ретельно досліджує його рослинність, проходячи щодня по 15-20 км. Результатом наукових досліджень ученого в Біловезькій Пущі стала публікація статей «Świerk w ostępach Białowieży» (1925), «Dąbrowy Białowieży» (1926), «Lipa w masywie Białowieżskim» (1928) та ін. У 1930 р. побачила світ капітальна монографія Пачоського «Lasy Białowieży».

Із 1925 року Й.К. Пачоський - професор кафедри систематики та соціології рослин на природно-математичному факультеті Познанського університету. 1926 року йому присвоюють почесне звання Doctor honoris causa. Спочатку Пачоський приїжджав із Біловезької Пущі до Познані для читання лекцій у зимовий період, а в 1928 р. він переселяється до міста. Працюючи тут, учений поєднує викладання лекцій із науково-дослідною 
роботою не тільки в межах Польщі, а й на Балканах. У 1929 р. Пачоський подорожує по Югославії, приділяючи особливу увагу вивченню лісів Боснії. Результати цих досліджень були викладені в праці «Lasy Bosni», опублікованій в журналі «Sylwan» (1929)*.

1930 року вчений здійснив експедицію до Болгаpiї, яка тривала 70 днів. Під час цієї експедиції було виявлено нові для флори Балкан види рослин. Зібраний гербарій (2800 зразків балканських рослин) був переданий до Гербарію Познанського університету.

У 1931 році Й.К. Пачоський вийшов на пенсію. Кафедру, яку він очолював, ліквідували, а іiі персонал перевели на кафедру загальної ботаніки. У 1932 р. Йосип Конрадович купив садибу Сєрослав (20 км на захід від Познані), де власноручно посадив понад 1000 саджанців плодових дерев і зайнявся вивченням їхньої екології та морозостійкості. Уже по смерті вченого, 1952 року, була надрукована його праця «Dynamika uszkodżeń mrozowych naszych drzew owocowych», написана за матеріалами власних помологічних спостережень.

1938 року Й.К. Пачоський поновив роботу в Познанському університеті й одержав звання заслуженого професора. Тут він продовжує працювати до 1939 р.

Під час німецько-фашистської окупації Польщі вчений перебував у Сєрославі. В лютому 1942 р. гестапівці по-звірячому побили його внука. Це потрясіння стало причиною смерті Йосипа Пачоського. Він помер 14 лютого 1942 р. на 78-му році життя від серцевого нападу. Його поховали на цвинтарі в селі Люсово, за 4 км від Серослава. 3 ініціативи Познанського відділення Польського ботанічного товариства прах Й.К. Пачоського в 1959 р. був перепохований на цвинтарі заслужених (Cmentarz Zasłużonych) у Познані. На пам'ятнику вченому написано: «Творцю фітосоціології доктору Honoris causa Познанського університету Йосипу Пачоському, досліднику великих територій польських, російських, балканських. Відділення Ботанічного товариства в Познані».

Наукова спадщина Й.К. Пачоського становить понад 300 праць у галузі ботаніки, зоології, географіï, лісознавства, наукознавства. Незважаючи на те, що Пачоський за фахом був зоологом (ентомологом), його внесок у ботанічну науку значніший, ніж у зоологічну.

\footnotetext{
* Paczoski J. Lasy Bosni // Sylwan, 1929, XLVII, 5. - S. 329377.
}

ISSN 0372-4123. Укр. ботан. журнн., 2014, m. 71, № 6
Талант Й.К. Пачоського як науковця-ботаніка повною мірою розкрився в таких чудових підручниках: «Основы фитосоциологии», «Морфология растений», «Wstęp do filogenii», «Podstawowe zagadnienia geografii roślin», у монографіях «Życie gromadne roślin», «Skice fitosocjologiczne», «Lasy Białowieży», «Biologiczna structura lasu», «Bioindukcia w państwie roślinnym», «Piętrowość lasu» і багатьох інших. Діапазон науково-дослідної діяльності Й.К. Пачоського в галузі ботаніки був надзвичайно широким - від морфології та систематики до фізіології рослин. Найбільший внесок він зробив у фітогеографію, систематику, фітосоціологію.

Як ботаніко-географ Й.К. Пачоський був одним із кращих знавців рослинного покриву Східної $\mathrm{C}_{\text {в- }}$ ропи на території від Литви до Чорного моря, від балканських лісів до калмицьких степів.

У своїх перших ботанічних працях Й.К. Пачоський описує флору й рослинність околиць міст Умані, Володимира-Волинського, Миколаєва та інших, а також окремих районів Полісся, ВолиноПоділля, Наддніпрянщини, Північного Причорномор'я. Цінність цих ранніх публікацій Й.К. Пачоського зростає з кожним роком. Детальні, майже топографічні описи флори та рослинності окремих регіонів, виконані молодим Пачоським, дають матеріал для порівняльного вивчення флори, дозволяють виявити іiі антропогенні зміни.

Найбільшим внеском у регіональну флористику є праця вченого «Флора Полесья и прилежащих местностей», опублікована в «Трудах СанктПетербургского общества естествоиспытателей» (1897-1900). I донині це - єдина робота з флори всього поліського регіону. 1900 року була видана праця Й.К. Пачоського «O formacyjach roślinnych i pochodzeniu flory poleskiej», яка є першим описом рослинних угруповань Полісся й першою роботою з генезису флори цього регіону.

Завдяки науковій діяльності Й.К. Пачоського в херсонський період причорноморські степи - один із найкраще досліджених у ботаніко-географічному аспекті регіонів України. У праці «Материалы для флоры степей юго-восточной части Херсонской губернии» (1890) Й.К. Пачоський подає детальний історичний огляд результатів вивчення флори Північного Причорномор'я. Слід зазначити, що раніше були лише фрагментарні, розрізнені відомості про флору цього регіону. В згаданій праці вчений уперше описує нові для науки види рослин - Cerastium schmalhausenii Pacz., Genista scythica 
Pacz., Centaurea hypanica Pacz., Nonea pulchella Pacz., Carex dubia Pacz. У 1914 р. Й.К. Пачоський публікує «Херсонскую флору», яку присвячує своїм учителям - В.Я. Скробишевському та І.Ф. Шмальгаузену. В об'ємній книзі (548 сторінок) автор описує папоротеподібні, голонасінні й однодольні рослини краю. Для написання «Херсонской флоры» були використані особисті гербарні матеріали Й.К. Пачоського, які зберігалися в музеї Херсонського губернського земства. Вчений навів детальні відомості про географічне поширення та умови місцезростань 335 видів рослин із 1500 видів флори Херсонської губернії.

Підсумком 30-річних фітосозологічних досліджень Й.К. Пачоського стала монографія «Szkice fitosocjologiczne» (1925), в якій він висвітлює історичний розвиток науки про рослинні угруповання 3 часів А. Гумбольдта, котрий першим почав уживати термін «асоціація». На підставі багаторічного досвіду вивчення рослинного покриву Пачоський виділяє різні типи асоціацій. Так, агрегації - це одновидові угруповання, в яких взаємини між рослинами виявляються слабо, асоціації - гетерогенні угруповання, що складаються з елементів, неоднорідних у генетичному, біологічному та екологічному аспектах. Рослини, що входять до складу угруповань, Й.К. Пачоський розподіляє на компоненти, котрі формують основу угруповань, та інгредієнти рослини, розміщені серед компонентів. Компоненти утворюють середовище рослинних угруповань і формують фітоклімат. Звертаючи увагу на специфічність кліматичного режиму різних рослинних угруповань, Й.К. Пачоський уперше обгрунтовує поняття «фітоклімат».

Йосип Конрадович уперше (1896 р.) ввів до наукового обігу термін «фітосоціологія» в Росії і в Польщі. У Франції цим терміном почали користуватися тільки в 1910 р., у США - 1917, в Скандинавських країнах - у 1919 р. У російській геоботаніці цей термін міцно утвердився з 1910 р. Палким його пропагандистом був В.М. Сукачов, який виступив на ХІІ з'їзді природознавців і лікарів, шоб підтримати цей термін. На III Всесоюзному з'їзді ботаніків у Ленінграді 1928 року фітосоціологія була піддана нищівній критиці. «Члени рослинного угруповання пов'язані між собою лише екологічно, екологія і є єдиним шляхом для вивчення закономірностей рослинного покриву; немає ніяких спеціальних фітосоціологічних методів і немає потреби вживати термін «“фітосоціологія”» - вказувалося в матеріалах з'їзду. Було прийнято рішен- ня замінити термін «фітосоціологія» на «фітоценологія», що тривалий час використовувався в радянській геоботаніці.

Свої фітосоціологічні ідеї Й.К. Пачоський розвивав у працях із лісознавства. Найвідомішою серед ботаніків і лісівників Європи є його капітальна монографія «Lasy Białowieży» (1930), в якій він подає докладний аналіз типів лісу, одним із перших застосовує біометричний метод для аналізу деревостанів. Усю різноманітність лісів Біловезької Пущі вчений зводить до шести основних типів:

1. Груди - широколистяні ліси з переважанням граба, за участю липи, ясена, береста, дуба, з підліском із неморальних трав, приурочені до найродючіших грунтів.

2. Олесогруди - заплавні ліси, основу яких утворює вільха чорна, за участю ясена, граба та дуба в притерасній частині.

3. Вільшняки - антропогеннопохідний тип; під впливом випасання худоби зникають лісові компоненти деревного ярусу, залишається тільки вільха.

4. Ялинники - найпоширеніший тип лісу в Пущі, спостерігається також значна інвазія підросту ялини в інші типи лісу.

5. Соснові бори - теж поширені в Біловезькій Пуші.

6. Діброви - займають найменшу площу серед лісових формацій Біловезької Пущі, при цьому виокремлюються діброви, утворені Quercus robur i $Q$. petraea.

Дібровам Біловезької Пущі Й.К. Пачоський приділяє особливу увагу. Він вступає в дискусію $з$ німецьким лісознавцем Ляутеншлагеном, який вважав, що діброви Біловезької Пущі мають штучне походження, оскільки приурочені до малопридатних грунтів і погано ростуть. У відповідь Пачоський зауважує, що рослини взагалі рідко зростають в оптимальних для них умовах. Найважливішим фактором їхнього поширення $є$ не фізичні умови місцезростання, а фітосоціальне середовище. На користь природного зростання дібров у Біловезькій Пуші свідчить наявність низки рослин, які приурочені лише до дібров, зокрема Adenophora liliifolia (L.) Ledeb. ex A. DC., Astrantia major L., Centaurea phrygia L., Cimicifuga foetida L., Inula hirta L., Laserpitium latifolium L., Peucedanum cervaria (L.) Lapeyr., Pimpinella magna L., Thalictrum simplex L., Trifolium rubens L. Ці види, а також Quercus petraea Liebl., Abies alba Mill., Taxus baccata L. i 
Hedera helix L. у Біловезькій Пущі є реліктами міжльодовикового періоду.

Йосип Конрадович Пачоський переконливо довів, що Біловезька Пуща є найкращим і найменш антропогеннопорушеним лісовим масивом Европи. До Пачоського серед лісознавців переважала думка, що такими є ліси Боснії (Rubner, 1925)**. У 1928 р. Й.К. Пачоський детально обстежив ліси Боснії та опублікував результати своїх досліджень у статті «Lasy Bosny» (Sylwan, 1929). Під час порівняльного вивчення лісів Біловезької Пущі та Боснії вчений дійшов висновку, що окремі невеликі масиви ялицево-ялинових лісів Боснії перевершують біловезькі ліси, проте загалом боснійські ліси сильно порушені через негативний вплив випасання худоби. У роботі «Biologiczna structura lasu» $\left(\right.$ Sylwan, 1928) ${ }^{* * *}$ Й.К. Пачоський розглядає ліс як складний комплекс рослинного світу, грунту, клімату та тваринного світу й рекомендує займатися лісовим господарством на екологічній основі.

У період 1915-1927 рр. була опублікована тритомна праця Й.К. Пачоського «Описание растительности Херсонской губернии»: том 1 - «Леса» (1915), том 2 - «Степи» (1917), том 3 - «Плавни, пески, солончаки, сорные растения» (1927). Надзвичайно цікавою та важливою є вступна глава книги, в якій автор розглядає загальні закономірності структури рослинних угруповань. У цій праці Й.К. Пачоський уперше ввів у науку нині загальнопоширені терміни: зональна, екстразональна, азональна рослинність.

Особливу наукову цінність становить синтетична теоретична праця Й.К. Пачоського «Основные черты развития флоры юго-западной России» (1910), у якій уперше сформульована гіпотеза про реліктовий характер флори Волино-Поділля, що стала джерелом формування флори Полісся та причорноморських степів. Ця книга ознаменувала кардинально новий етап осмислення флористичних досліджень.

Йосип Конрадович Пачоський вніс свій вклад не тільки у вивчення рослинного покриву України та Молдови, а й степів Калмикії. В опублікованій 1892 р. праці «Флористические и фитогеографические исследования калмыцких степей» він наводить першу ботаніко-географічну характеристику

\footnotetext{
** Rubner K. Die forstliche Bedeutung der Waldtypen // Forstarchiv, 1926

*** Paczoski J. Biologiczna struktura lasu // Sylwan, 1928, XLVI, 3. - S. 193-221.
}

цього унікального регіону, розміщеного на кордоні між Європою та Азією.

Пачоський був також систематиком рослин. Він описав нові для науки види: Cytisus skrobiszewskii, Genista scytica, Euphorbia tanaitica, Asperula taurica, Ranunculus zapałowiczii, Cerastium schmalhauzenii, Juncus tyraicus, Nonea pulchella, Papaver albiflorum. Типи цих видів зберігаються в гербарії Херсонського краєзнавчого музею. Крім того, вчений був також автором обробки родини Ranunculaceae у «Флорі Польщі» (Flora Polska, 1927).

Й.К. Пачоський є засновником нової науки науки про рослинні угруповання, або фітосоціології. Свої перші фітосоціологічні ідеї він виклав у праці «Стадии развития флоры» (1891), де обгрунтував виділення нової науки про генезис, життя та розвиток рослинних асоціацій (формацій) і назвав цю науку флорологією, вказавши на ііі близькість до соціології. Вчений пише про те, що рослинні угруповання мають свою структуру і є стадіями розвитку рослинного покриву, формуючись від більш простих за структурою і біологією до більш складних. Не зовсім вдалий термін «флорологія» для окреслення науки про рослинні угруповання Й.К. Пачоський у книзі «Życie gromadne roślin» (1896) замінив на більш вдалий - «фітосоціологія».

Наукові здобутки Й.К. Пачоського були високо оцінені ще за його життя. «Начав с юных лет свое знакомство с растительностью юга России, Иосиф Конрадович Пачоский является в настоящее время лучшим знатоком этой флоры», - писав В.І. Липський. Високо оцінив природоохоронну діяльність ученого також І.П. Бородін у своїй доповіді на Першій міжнародній конференції з охорони природи. Свідченням високих наукових заслуг Й.К. Пачоського $є$ названі на його честь види рослин - Centaurea paczoskii Kotov ex Klokov, Cytisus paczoskii V. Krecz. (= Chamaecytisus paczoskii (V. Krecz) Klásk.), Gagea paczoskii (Zapał.) Grossh., Lamium paczoskianum Vorosch., Allium paczoskianum Tuzson, Corydalis paczoskii N. Busch, Jurinea paczoskiana Iljin, Pyrethrum paczoskii Zefir. (= Tanacetum paczoskii (Zefir.) Tzvelev), Carex paczoskii Zapał., Hieracium paczoskianum Sennikov, Onobrychis paczoskiana Krytzka, Papaver paczoskii Mikheev, Poa paczoskii Tzvelev, Veronica paczoskiana Klokov.

У 1932 р. на честь 45-річчя наукової діяльності Й.К. Пачоського йому був присвячений окремий випуск журналу «Acta Societatis Botanicorum Poloniae». 
Уже після смерті вченого 1951 року в Польщі були видані «Dzieła wybrane», куди ввійшли «Szkice fitosocjologiczne», «Podstawowe zagadnienia geografii roślin» і вступ до книги «Lasy Białowieży».

До 100-річчя від дня народження вченого Познанський університет імені Адама Міцкевича випустив збірник «Józef Paczoski, w setną rocznicę urodzin» (1967), а також перевидав два томи класичної праці Й.К. Пачоського «Херсонська флора». У 2012 році Познанське товариство приятелів наук разом із Університетом імені Адама Міцкевича видало збірник наукових праць Пачоського під назвою «Rozważania o siecie powiązań w świecie roślin». Вступ написав і підібрав тексти Кароль Лятовський.

У Познанському університеті $€$ аудиторія Й.К. Пачоського, у спеціальному архіві зберігаються його праці, рукописи, фотографії. В Ботанічному саду цього ж університету та в Біловезькій Пущі встановлені пам'ятні знаки вченому.

В Україні, починаючи від 1989 року, через кожні п'ять років організовуються «Ботанічні читання пам'яті Й.К. Пачоського». Уже проведено п'ять таких читань. У 1993 році відкрито меморіальну кімнату вченого в Херсонському краєзнавчому музеї, а в 2003 Лабораторії біорізноманіття та екологічного моніторингу Херсонського педагогічного університету присвоєно ім'я Й.К. Пачоського. У 2013 році вчені Одеського університету видали каталог «Гербарна колекція Й.К. Пачоського».

\section{СПИСОК ОСНОВНИХ ПРАЦЬ ПРО ЖИТТЯ ТА НАУКОВУ ДІЯЛЬНІСТЬ Й.К. ПАЧОСЬКОГО}

Бойко М.Ф. Другі наукові читання пам'яті Й.К. Пачоського // Укр. ботан. журн. - 1995. - 52, № 5. -С. 748-751.

Бойко М.Ф., Горлова Н.У. Гербарій Й.К. Пачоського в Херсонському краєзнавчому музеї // Укр. ботан. журн. 1986. - 71, № 1. - С. 85-86.

Борейко В.Е. Йосип Конрадович Пачоський // Рідна природа. - 1986. - № 4. - С. 61-62.

Бородин И.П. Отчет о командировке в Берн на Конференцию по международной охране природы // Мировая охрана природы. - Петроград, 1915. - С. 3-7.

Вайнер (Уинер) Д. Экология в Советской России. Архипелаг свободы: Заповедники и охрана природы. - М.: Прогресс, 1991. - 397 с.

Доброчаєва Д.М. Йосип Конрадович Пачоський (до 120-річчя 3 дня народження) // Укр. ботан. журн. 1985. - 42, № 1. - С. 95-97.

Дрогобич Н.Ю. Пачоський Йосип Конрадович. Асканія-Нова, 1998. - 6 с.

Липский В.И. Биография и международная деятельность ботаников и лиц, соприкасавшихся с Императорским ботаническим садом. - Петроград, 1915. - Вып. 3. $-536 \mathrm{c}$.
Мельник В.И. И.К. Пачоский как ботаник и лесовед // Леса Евразии в XXI веке: восток-запад: Мат-лы II Междунар. конф. мол. ученых, посвященной профессору И.К. Пачоскому. - М: Наука, 2002. - С. 8-9.

Пузанов И.И., Гольд Т.М. Выдающийся натуралист И.К. Пачоский. - М.: Наука, 1965. - 87 с.

Bukowiecki H., Felisiak S. Paczoski Józef // Słownik biologów polskich. - Warszawa: PWN, 1987. - S. 407-409.

Curriculum vitae и списки работ почетных членов Общества сельского хозяйства южной России - А. Браунера, Г. Высоцкого и И. Пачоского // Зап. Об-ва сельск. хоз-ва Южной России. - 1917. - Кн. 2. - С. 84-93.

Dzieczkowski S. Paczoski Józef //Polski słownik biograficzny. 1979. - T. 24. - S. 786-789.

Hryniewiecki B. Józef Paczoski. Wspomnienie // Las Polski. 1946. - 6. - S. 9-10.

Latowski K. Z kart drogi życiowej Profesora Jósefa Paczoskiego// Józef Paczoski. Rozważania o świecie powiazań w świecie roślin. - Poznań: PTP, 2012. - 354 s.

Melnik W.I. Józef Paczoski - botanik i leśnik // Wiadomości Botaniczne. - 2003. - 47(3/4). - S. 39-47.

Paczoski J. W setną rocznicę urodzin / Red. Z. Czubiński. Poznań, Universytet im. Adama Mickiewicza w Poznaniu. Prace wydziału biologii i nauk o ziemi. - Seria biol. 1967. - N 31. - 108 s.

Szafer $W$. Dr. Józef Paczoski // Chrońmy Przyrodę ojczystą. 1945. - N 1. - S. 38.

Wodziczko A. Zasługi naukowe Profesora Paczoskiego // Sylwan. - 1931. - 49(3). - S. 1-21.

Wodziczko A. Józef Paczoski. Spis ważniejszych prac naukowych prof. Paczoskiego // Acta Societais Botanicorum Poloniae. - 1932. - Vol. 19. Supl. - S. 1-15.

Рекомендує до друку

Надійшла 07.07.2014 p.

С.Л. Мосякін

\section{В.И. Мельник}

Национальный ботанический сад имени Н.Н. Гришко НАН Украины, г. Киев

ИОСИФ КОНРАДОВИЧ ПАЧОСКИЙ (к 150-ЛеТИю со дня рождения)

В статье освещена деятельность выдающегося ученого Иосифа Конрадовича Пачоского (1864-1942) - основателя фитосоциологии, всемирно известного ученого в области систематики растений, флористики, лесоведения, зоологии и охраны природы.

Ключе в ы е сло в а: И.К. Пачоский, ботаника, флора, систематика растений, фитосоциология, зоология.

\section{V.I. Melnik}

M.M. Gryshko National Botanical Garden, National Academy of Sciences of Ukraine, Kyiv

\section{JOZEF K. PACZOSKI (150 ${ }^{\text {th }}$ Anniversary)}

The paper is dedicated to the founder of phytosociology, Professor J.K. Paczoski (1864-1942), a scientist known worldwide in the fields of plant systematics, floristics, forestry, zoology and nature conservation.

Ke y wo rds: J. K. Paczosky, botany, flora, plant systematics, phytosociology, zoology.

ISSN 0372-4123. Ukr. Bot. J., 2014, 71(6) 